\title{
Long-term safety, efficacy and side-effects of continuous subcutaneous insulin infusion treatment for Type 1 (insulin-dependent) diabetes mellitus: a one centre experience
}

\author{
E.Chantelau, M.Spraul, I. Mühlhauser, R. Gause and M. Berger \\ Department of Nutrition and Metabolism (WHO Collaborating Center for Diabetes), Heinrich Heine University, Düsseldorf, FRG
}

\begin{abstract}
Summary. A follow-up study of 116 Type 1 (insulin-dependent) diabetic patients on long-term continuous subcutaneous insulin infusion was conducted after $4.5 \pm 0.2$ years. The average $\mathrm{HbA}_{1 \mathrm{c}^{-v a l u e}}$ of these patients decreased by $1 \%$ to $6.7 \pm 0.1 \%$ during this observation period. Typical side effects of continuous subcutaneous insulin infusion such as skin inflammation at the catheter insertion site occurred with similar frequency as has been reported previously by other authors. Diabetic ketoacidosis ( 0.14 per patient year) and disabling hypoglycaemia ( 0.1 per patient year, including 0.05 hypoglycaemic coma per patient-year) occurred at substantially lower rates than in other comparable studies with Type 1 diabetic patients at a similar degree of metabolic control. Subgroup
\end{abstract}

evaluation suggested that a normal $(<5.6 \%) \mathrm{HbA}_{1 c^{-v a l u e ~ a t ~}}$ follow-up was associated with increased incidence of disabling hypoglycaemia, whereas poor metabolic control $\left(\mathrm{HbA}_{1 \mathrm{c}}>7.5 \%\right)$ was associated with increased rates of skin complications and hospital treatment for ketoacidosis. Thus, under the policies of this diabetes centre, continuous subcutaneous insulin infusion has proved to be beneficial to a large proportion of experienced adult Type 1 diabetic patients, who voluntarily had opted for, and continued with, this particular mode of insulin treatment.

Key words: Insulin therapy, insulin pumps, diabetes complications, blood glucose self-monitoring, diabetes diet.
Four years after Slama et al. had introduced continuous ambulatory i.v. infusion of regular insulin into diabetes management [1], Pickup et al. in 1978 modified this approach into continuous subcutaneous insulin infusion (CSII) therapy with portable mini-pumps [2]. This method was approved in 1985 by the American Diabetes Association [3] as an alternative to conventional insulin injection therapy for the treatment of Type 1 (insulin-dependent) diabetes mellitus.

Improvement in acute metabolic control which may be achieved with CSII compared to conventional insulin therapy [4-7], as well as side effects of CSII (diabetic ketoacidosis, severe hypoglycaemia and skin complications at the catheter insertion site [4]) have been noted. Little is known as to the long-term efficacy of CSII therapy, most of the previous papers providing intermediate-term observations at best [4-13]. Only a few studies have reported follow-up results of more than two years [14-18], some of these with rather disappointing results, e.g. frequent failure to maintain improved metabolic control, a high rate of rejection of CSII by the patients $[14,17]$ and a number of deaths have been associated with long-term CSII $[15,17,18]$. These drawbacks could either have been caused by the technique of CSII itself, or by the particular conditions of care offered by the different diabetes centres conducting CSII. The aim of the present study was, therefore, to investigate the feasibility and outcome of CSII over an extended period of time, with particular respect to the treatment conditions as offered by our diabetes centre.

\section{Subjects and methods}

All 140 patients with Type 1 diabetes [19] who had been initiated on CSII according to the Helsinki Declaration [20] at our department between March 1980 and May 1986 were followed-up between June and December 1987. At follow-up, 24 of the 140 patients had resumed insulin injection therapy; their clinical data, with the obvious exception of them still being alive and having discontinued CSII therapy, was incomplete and will therefore not be considered in this report.

We re-examined all 116 patients continuing CSIl at the time of follow-up after 1-7 ycars, i.e. after a mcan of $4.5 \pm 0.2$ years, giving a total observation time of 518 patient-years of CSII. The social status of the patients, 60 men and 56 women, was as follows: 62 employees, 18 housewives, 17 students, 10 self-employed, 8 retirces and 1 unemployed patient. The age of the patients at the beginning of CSII was $29 \pm 1$ years and the duration of diabetes was $14 \pm 1$ years. Twentytwo patients $(19 \%)$ had random C-peptide levels $\geqslant 0.4 \mathrm{ng} / \mathrm{ml}, 48 \mathrm{pa}-$ tients $(41 \%)$ had clinical evidence of diabetic late complications. Ten patients received antihypertensive treatment. For further details see Table 1. 
Table 1. Clinical characteristics of the 116 patients studied before and after a mean of 4.5 years of continuous subcutaneous insulin infusion treatment (means \pm SEM)

\begin{tabular}{|c|c|c|c|c|}
\hline \multirow[b]{2}{*}{ Weight (kg) } & \multicolumn{2}{|c|}{$\begin{array}{l}\text { Initial fasting } \\
\text { values }\end{array}$} & \multicolumn{2}{|c|}{$\begin{array}{l}\text { Follow-up } \\
\text { non-fasting values }\end{array}$} \\
\hline & 68.3 & \pm 0.7 & 70.6 & $\pm 0.8^{\mathrm{a}}$ \\
\hline Body mass index $\left(\mathrm{kg} / \mathrm{m}^{2}\right)$ & 22.9 & \pm 0.2 & 23.6 & $\pm 0.2^{\mathrm{a}}$ \\
\hline $\begin{array}{l}\text { Total cholesterol } \\
(\mathrm{mmol} / \mathrm{l})\end{array}$ & 5.1 & \pm 0.1 & 5.35 & \pm 0.1 \\
\hline $\begin{array}{l}\text { HDL-cholesterol } \\
(\mathrm{mmol} / \mathrm{l})\end{array}$ & 1.3 & \pm 0.03 & 1.43 & \pm 0.05 \\
\hline Triglycerides $(\mathrm{mmol} / \mathrm{l})$ & 1.1 & \pm 0.05 & 1.46 & $\pm 0.13^{a}$ \\
\hline Serum-creatinine $(\mu \mathrm{mol} / \mathrm{l})$ & 89 & \pm 2 & 84 & \pm 3 \\
\hline $\mathrm{HbA}_{1 \mathrm{c}}(\%)$ & 7.7 & \pm 0.1 & 6.7 & $0.1^{\mathrm{a}}$ \\
\hline $\begin{array}{l}\text { Blood pressure }(\mathrm{mm} \mathrm{Hg}) \\
\text { systolic } \\
\text { diastolic }\end{array}$ & $\begin{array}{r}125 \\
80\end{array}$ & $\begin{array}{l} \pm 1 \\
\pm 1\end{array}$ & $\begin{array}{r}128 \\
81\end{array}$ & $\begin{array}{l} \pm 1^{\mathrm{a}} \\
\pm 1\end{array}$ \\
\hline
\end{tabular}

${ }^{a}$ denotes significant difference between means at $p<0.05$

\section{Therapeutic principles and definitions}

Principles of CSII technology [4, 21.26], and particular aspects of CSII therapy as offered by this department [11, 25-27] have been published previously. Wc initiated CSII only at the request of patients already familiar with intensificd insulin injection therapy [28, 29]. These patients wanted to try CSII for further improvement of $\mathrm{HbA}_{1 \mathrm{c}}$ levels, or for more flexibility of life-style, which they had been unable to achieve with multiple injection therapy.

For the purpose of this study, diabetic ketoacidosis (DK $\Lambda$ ) was defined as nausea or vomiting in the presence of hyperglycaemia (blood glucose above $13 \mathrm{mmol} / \mathrm{l}$ ) and moderate or severe ketonuria. In this case, patients were instructed that extra insulin should be given subcutaneously by insulin syringe (e.g. $10 \mathrm{U}$ of regular insulin every hour until the symptoms disappeared).

Disabling hypoglycaemia (DH) was defined as a state of neuroglycopenia leading to an impairment or loss of consciousness with the need for external help. DH was to be prevented, e.g. by an appropriate reduction of insulin dosage in relation to heavy exercise, and a target level of fasting blood glucose $\geqslant 5.0 \mathrm{mmol} / \mathrm{l}$, since lower fasting glycaemia during CSII may be associated with substantial hyperinsulinaemia $[25,30]$ and nocturnal hypoglycaemia. To prevent late postprandial hypoglycaemia due to inappropriately high doses of prandial insulin, the portion of carbohydrates per meal should not exceed $80.100 \mathrm{~g}$ and the required insulin bolus therefore should not exceed 10-15 U. Blood glucose self-monitoring (BGSM) should be performed before each main meal, and if possible, before each single insulin bolus and at bed-time. Diet could be liberalised to a certain extent $[11,31,32]$ as described previously. Recommendations as to the handling of the insulin infusion catheters have been changed slightly over the years. Since 1986, polyethylene-made rather than PVC-made catheters [33], with skin disinfection before catheter insertion [27] have been advised. The catheters should be renewed every 2 to 3 days, and should not be reused. Only insulin pumps with satisfactory precision allowing changes in basal infusion rates (approximately $1 \mathrm{U} /$ day), with alarm functions, and with acceptable feasibility of handling have been recommended at this centre [34]. Pumps from 8 different manufacturers were used. Human and porcine regular insulins from four different manufacturers (Novo, Bagsvaerd, Denmark; Nordisk, Gentofte, Denmark; Eli Lilly Corp., (jiessen, FRG; Hoechst, Frankfurt, FRG) in concentrations of $40 \mathrm{U} / \mathrm{ml}$ and $100 \mathrm{~L} / \mathrm{ml}$ were used. All costs for CSII treatment (i. e. for the devices, the initial hospital stay, cannulas, dressings insulin, BGSM test strips, skin disinfectant) were covered by the patients' health insurance. The patients were offered routine diabetes care at our diabetes outpatient clinic every weekday morning, and Monday and Thursday evenings. A 24-h telephone service providing contact with a diabetes nurse or physician was also available.

\section{Methods}

Baseline data (obtained under fasting conditions) were taken from the clinical records of the 116 patients at initiation of CSII. The follow-up investigations were carried out in our outpaticnt clinic $(n=96)$ or in the patients' homes $(n=20)$. A standardised questionnaire was completed concerning details of their dietary habits, and of their current and previous CSII therapy, particularly the occurrence, causes, and management of DK $\Lambda$ and $D H$. Hospitalisation for diabctes-related and un-related causes was also evaluated by the questionnaire, if necessary additional information was obtained from the patients records kept either by our outpatient clinic $(n=82)$, by their family physicians $(n=29)$, or by other hospitals $(n=5)$. The patients were asked to present their diabetes diaries for analysis of their entries [28, 29]. Under random, non-fasting conditions, bodily measurements were taken, and a venous blood sample was drawn for determination of HLA-status, plasma glucose, blood lipids, creatinine and C-peptide, using routine laboratory methods, and for determination of $\mathrm{HbA}_{1 \mathrm{c}}$. The insulin infusion sites were also inspected.

$\mathrm{Hb} \Lambda_{1 \mathrm{c}}$ was determined previously in our laboratory by the modified thiobarbiturate (TBA) method [28,36]. In 1986, this method was replaced by HPLC-determination [35, 36], using the Diamat Analyser (Biorad Laboratories, Munich, FRG) [37] with a normal mean $\mathrm{HbA} / \mathrm{c}$ of 4.83 (standard deviation 0.31 ) $\%$ of total $\mathrm{Hb}$. In order to compare the TB $\wedge$ determined values with HPLC determined values, the former were converted into the latter by the formula given by Mecklenburg et al. [15]. A spot urine sample was obtained for measurement of proteinuria using a lascr-turbidimetric method [38].

\section{Statistical analysis}

Means \pm SEM are given, unless otherwise stated. Comparisons were performed with Chi-square, and t-test when appropriatc. A p-value of $<0.05$ was considered statistically significant. For subgroup analysis, standardised incidence ratios and $95 \%$ confidence intervals were calculated according to Morris and Gardner [39] by the use of Poisson distribution tables.

\section{Results}

\section{Clinical characteristics (Table 1)}

After $4.5 \pm 0.2$ years of CSII, all 116 patients were still alive. Their $\mathrm{HbA}_{1 \mathrm{c}}$ had decreased significantly from $7.7 \pm 0.1 \%$ to $6.7 \pm 0.1 \%$ at follow-up $(p<0.001)$. On the other hand, body mass index, and blood lipids were slightly elevated compared to the initial data, due to the fact that random (post prandial) measurements were taken at follow-up with the patients in street clothing, but fasting measurements were taken with the patients in underwear at initiation of CSII.

The patients random plasma glucose at follow-up was $6.4 \pm 0.4 \mathrm{mmol} / 1$; other blood chemistry showed that 5 patients had serum creatinine $\geqslant 110 \mathrm{\mu mol} / \mathrm{l}$. Urinalysis showed 86 patients with normal proteinuria $(<50 \mathrm{mg} / \mathrm{l})$, and 6 patients with macro-proteinuria ( $>500 \mathrm{mg} / \mathrm{l})$ at follow-up. 


\section{Diet parameters and insulin dosage}

The patients reported having $3.9 \pm 0.1$ daily meals, with an average carbohydrate intake of $160 \pm 5 \mathrm{~g}$ /day. Fifty percent of patients reported never drinking alcohol, whereas $7 \%$ of patients drank alcohol every day. The current basal insulin infusion rate at follow-up was $21.8 \pm 0.6 \mathrm{U}$ per day, and the total daily insulin dosage $41.8 \pm 1.0 \mathrm{U}$, i.e. approximately $0.6 \mathrm{U} / \mathrm{kg}$ body weight.

\section{Diabetic ketoacidosis (DKA)}

There were 74 episodes of $D K \wedge$ during the total followup period of 518 patient years of CSII, i. e. an annual incidence of $0.14 \mathrm{DKA}$ per patient. Thirty-four cases of DKA (0.06 DKA per patient-year) were treated in hospital; the remaining 40 cases were treated at home by repeated s.c. injection of regular insulin by the patients themselves, or relatives and friends. The 24-h telephone service had been contacted in only 15 of the DKA cases. Catheter defects (e.g. disconnected tubing) or inflamed insulin infusion sites were the main reasons for DKA ( $40 \%$ of cases). In $20 \%$ of cases, febrile illness was reported as the precipitating cause, whilst in the remaining 30 cases, no obvious cause was reported by the patients.

\section{Disabling hypoglycaemia ( $D H)$}

There were 54 cases of DH during the 518 patient years, i.e. an annual incidence of 0.10 per patient. Hospital treatment or calling for an emergency care physician to inject glucose i.v. was necessary in 19 cases of $\mathrm{DH}(0.04$ per patient-year), whereas the remaining 35 cases were managed by relatives or friends injecting glucagon $(n=8)$ or giving oral carbohydrate. Hypoglycaemic coma occurred 0.05 times per patient-year. All cases of DH recovered without further problems. The predominating reasons for $\mathrm{DH}$ were accidental overdoses of prandial insulin $(n=20)$ and exercise $(n=12)$. During pregnancies, $4 \mathrm{DH}$ occurred, and $8 \mathrm{DH}$ were reported in relation to alcohol ingestion. Unidentified causes of DH $(n=10)$ may include cases of circulating anti-insulin antibodies [24] or malfunction and mismanagement of the devices.

\section{Skin complications}

The patients reported a total of 134 cases of s.c. inflammation, i.e. 0.26 cases of inflammation per patient-year, 35 of which required antibiotic treatment and/or surgery. At follow-up examination, $48 \%$ of the patients had whitish scars on their abdominal skin, described as being the result of previous infections of the insulin infusion sites [27]. On inspection, in 51\% of the patients erythema was present at the insertion site of the catheter needle currently used, subcutaneous nodules were palpable in $19 \%$, and inflammation requiring antibiotic treatment was found in $1.7 \%$ of the patients.

\section{Hospitalisation}

During the 518 patient-years of follow-up, 77 out of 116 patients $(66 \%)$ were hospitalised for diabetesrelated and un-related causes for a total of 1606 days. Of these 3.1 days per patient-year in hospital a total of 1.0 days were related to 18 pregnancies, with the remaining 2.1 days being due to the treatment of metabolic disturbance, various operations, injuries, and treatment of diabetic eye disease.

\section{Subgroup description}

In order to identify possible associations between the degree of metabolic control and patients' characteristics and complications of CSII, patients were grouped deliberately according to their $\mathrm{HbA}_{1 \mathrm{c}}$ at follow-up: $16 \mathrm{pa}$ tients $(14 \%)$ with normal $\mathrm{HbA}_{1 \mathrm{c}}$ (normal metabolic control) represented 70 patient-years. Twenty-eight patients (24\%) with $\mathrm{HbA}_{1 \mathrm{c}}$ between $5.6 \%$ and $6.25 \%$ (excellent control) represented 115 patient-years; 53 patients (46\%) with $\mathrm{HbA}_{1 \mathrm{c}}$ between 6.26 and 7.5 (good control) represented 246 patient-years. The remaining 19 patients $(16 \%)$ with $\mathrm{HbA}_{1 \mathrm{c}}$ exceeding $7.5 \%$ (poor control) represented 87 patient-years.

There were no differences between these four groups with respect to sex, age, HLA-status (data not shown), duration of diabetes, duration of CSII, prevalence of late diabetic complications, or the prevalence of serum-C-peptide $\geqslant 0.4 \mathrm{ng} / \mathrm{ml}$. Also, present nonsmokers and non-drinkers (approximately $50 \%$ in each group) as well as patients drinking alcohol daily, were evenly distributed between the groups. For further details of patient characteristics, see Table 2. There were no differences between these patient groups with respect to insulin dosage, meal frequency ( 2 to 5 per day), renewal of catheters ( 2 to 4 times per week), and outpatient clinic visits (1 to 12 times per year). Poorly controlled patients, however, differed with regard to the incidence of treatment complications. Poorly controlled patients reported more cases of inflammation of the infusion site and were hospitalised more often for treatment of DKA than patients with normal $\mathrm{HbA}_{1 \mathrm{c}}$, whereas patients with normal $\mathrm{HbA}_{1 \mathrm{c}}$ reported more cases of disabling hypoglycaemia (Table 3). Mean annual duration of hospitalisation for any reason was 4.0 days in patients with normal $\mathrm{HbA}_{1 \mathrm{c}}, 3.1$ days in patients with excellent control, 3.0 days in patients with good control and 2.7 days in patients with poor control (NS).

\section{Discussion}

The present study confirms previous short-term observations $[5-7,9-13,40]$ that CSII is effective in improving metabolic control in Type 1 diabetes. In our study, CSII was accepted and maintained as routine therapy for a mean of 4.5 years by $83 \%$ of patients in whom it 
Table 2. Characteristics of continuous subcutaneous insulin infusion trcatment as observed in patients with normal, excellent, good, and poor metabolic control at follow-up

\begin{tabular}{|c|c|c|c|c|}
\hline & \multicolumn{4}{|c|}{$\mathrm{HbA}_{1 \mathrm{c}}$-value } \\
\hline & $<5.6 \%$ & $5.6-6.25 \%$ & $6.26-7.5 \%$ & $>7.5 \%$ \\
\hline Metabolic control & Normal & Excellent & Good & Poor \\
\hline No. of patients & $n=16$ & $n=28$ & $n=53$ & $n=19$ \\
\hline \multicolumn{5}{|l|}{$\begin{array}{l}\% \text { of patients performing } \\
\text { blood glucose self- } \\
\text { monitoring approx. }\end{array}$} \\
\hline$<3 /$ day & $0 \%$ & $4 \%$ & $11 \%$ & $11 \%$ \\
\hline 3. $5 /$ day & $63 \%$ & $86 \%$ & $79 \%$ & $79 \%$ \\
\hline $\begin{array}{l}\% \text { of patients keeping } \\
\text { a diabetes diary }\end{array}$ & $75 \%$ & $64 \%$ & $76 \%$ & $53 \%$ \\
\hline$\%$ of patients using & & & & \\
\hline U-100 insulina & $75 \%$ & $50 \%$ & $57 \%$ & $74 \%$ \\
\hline U-40 insulin ${ }^{a}$ & $25 \%$ & $50 \%$ & $43 \%$ & $26 \%$ \\
\hline $\begin{array}{l}\% \text { of patients using } \\
\text { stepped up supplemen- } \\
\text { tary infusion rate at dawn }\end{array}$ & $13 \%$ & $21 \%$ & $8 \%$ & $5 \%$ \\
\hline
\end{tabular}

${ }^{\mathrm{a}} \mathrm{U}-100 / \mathrm{U}-40$ denotes the insulin concentration in units $/ \mathrm{ml}$

Table 3. Incidence of complications of continuous subcutaneous insulin infusion per patient-year, according to normal, excellent, good, and poor metabolic control at follow-up

\begin{tabular}{lllll}
\hline & \multicolumn{3}{l}{$\mathrm{Hb}_{1 \mathrm{c}^{-} \text {value at follow-up }}$} & \\
\cline { 2 - 5 } & $<5.6 \%$ & $5.6-6.25 \%$ & $6.26 \cdot 7.5 \%$ & $>7.5 \%$ \\
\hline $\begin{array}{l}\text { Metabolic control } \\
\begin{array}{l}\text { Diabetic keto- } \\
\text { acidosis (all) }\end{array}\end{array}$ & Normal & Excellent & Good & Poor \\
$\begin{array}{l}\text { Diabctic keto- } \\
\text { acidosis (requiring }\end{array}$ & 0.142 & 0.113 & 0.146 & 0.172 \\
$\begin{array}{l}\text { in-hospital treatment) } \\
\begin{array}{l}\text { Disabling hypo- } \\
\text { glycaemia }\end{array}\end{array}$ & 0.014 & 0.052 & 0.073 & 0.104 \\
$\begin{array}{l}\text { Subcutaneous in- } \\
\text { flammation at } \\
\text { the needlc site }\end{array}$ & $0.242^{\mathrm{a}}$ & 0.147 & $0.065^{\mathrm{b}}$ & $0.042^{\mathrm{b}}$ \\
\hline
\end{tabular}

a significantly different at $p<0.05$ as compared to ${ }^{b}$ in the same line

was initiated. The mean $\mathrm{HbA}_{1 \mathrm{c}}$ of $6.7 \%$ (equivalent to an average blood glucose level of approximately $7.6 \mathrm{mmol} / 1$ [41]), indicates satisfactory metabolic control for most of the patients at follow-up. The clinical characteristics of these CSII patients were similar to those of a comparable non-diabetic population in Britain [42] except for plasma glucose. No deaths occurred in our study compared to 0.009 to 0.04 deaths per patient-year on CSII, as reported by others $[17,43]$. These favourable results may have been promoted by several factors:

1. The participants in this study were in fairly good control with multiple injection therapy [28] prior to initiation of CSII, reflected by the mean $\mathrm{HbA}_{1 \mathrm{c}}$ value of $7.7 \%$.

2. All of the patients in our study were adults with a mean of 14 years experience in diabetes management, who intended to improve their metabolic control/lifestyle by means of CSII.

3. Our patients' frequency of BGSM was rather high (an average of 4 times per day). The patients of Knight et al. performed BGSM on an average of 13 times per week [18]. Schiffrin et al. [44] and Nathan et al. [45] have documented that tight metabolic self-monitoring is essential for successful intensive insulin therapy; thus the effectiveness of intensive insulin therapy (including CSII) appears to decrease with a decreased frequency of BGSM and insulin dose adjustment [46, 47].

Our patients experienced DKA with an annual frequency of 0.14 per patient year, whereas the group of Peden et al. [48] reported 0.22 DKA per patient-year, and the Kroc Collaborative Study group observed approximately 0.4 DKA per patient-year [12]. Note that the incidence of DKA during conventional insulin injection therapy may range from 0.008 DKA per patient year [49] to 0.28 DKA per patient-year [43]. As we have previously shown in unselected Type 1 diabetic patients on insulin injection therapy [29], the rate of DKA depends primarily on the standards of diabetes education and self-care. In that study the annual rate of severe DKA (defined as hyperglycaemia plus clinical signs of ketoacidosis, an arterial $\mathrm{pH}$ value of $<7.3$, and hospital treatment) was reduced to nearly zero by improved diabetes self care [29]. As this was not achieved in the present study with CSII-treated patients, CSII appears to carry a particular risk for DKA.

The underlying cause of this side effect has recently been identified as a reduced tolerance for the interruption of CSII. Due to the relatively small amount of insulin deposited in the subcutaneous tissue during CSII, relevant insulin deficiency may develop only $3-4 \mathrm{~h}$ after cessation of the insulin infusion [50-53]. On the other hand, CSII functions with the least possible peripheral (hyper-)insulinaemia $[25,30]$ and with overall reduced insulin dosages compared to injection treatment [5-7]; hence, an accidental interruption of CSII can be quite detrimental.

Disabling hypoglycaemia was observed at an annual rate of $0.10 \mathrm{DH}$ per patient. This rate is in agreement with previous reports ranging from $0.09 \mathrm{DH}$ per patient year [16] to $0.13 \mathrm{DH}$ per patient year [13], and $0.19 \mathrm{DH}$ per patient year as reported by our group after observation of the first 46 patient years of CSII [9]. Note that the incidence of $\mathrm{DH}$ during conventional insulin injection treatment is similar (ranging from 0.16 to 0.4 per patient year as reported by Home et al. [54]).

However, the incidence of 'severe hypoglycaemia' in this study was substantially lower than the incidence of severe hypoglycaemic reactions as reported for the intervention group (i.e. 0.54 per patient year) at comparable degrees of glycaemic control in the DCCT [35].

Finally, there is a relatively high incidence of infected infusion sites in our study which is explained by the fact that our patients were advised to use topical dis- 
infectant prior to insertion of the needle only after 1986 [27]. Since then, the rate of serious infections has declined substantially (unpublished observations).

To compare the outcome of CSII at different levels of glycaemic control, patients were grouped according to their $\mathrm{HbA}_{1 \mathrm{c}}$ value $[55,67]$. Because the degree of glycaemic control as obtained by each individual patient may remain fairly constant over a long period of time [57-59], we took the $\mathrm{HbA}_{1 \mathrm{c}}$ at follow-up as representative of the individually achieved degree of diabetes control.

Fourteen percent of the patients were controlled with $\mathrm{HbA}_{1 \mathrm{c}}$ values within 2 standard deviations from the mean normal value, and $38 \%$ of the patients had $\mathrm{HbA}_{1 \mathrm{c}}$ values below $6.25 \%$. This is about twice the proportion of Type 1 diabetic patients with a similar degree of diabetic control under traditional treatment, both 10 years ago [60] and at present [55].

Slightly supranormal $\mathrm{HbA}_{\mathrm{ic}}$ levels (i.e. excellent control, $\left.\mathrm{HbA}_{\mathrm{Ic}} 5.6-6.25 \%\right)$ in this study was associated with a lower incidence of DH $(0.147 \mathrm{DH}$ per patientyear) compared to normal $\mathrm{HbA}_{1 \mathrm{c}}$ (i.e. normal metabolic control, $\mathrm{HbA}_{1 \mathrm{c}}<5.6 \%, 0.242 \mathrm{DH}$ per patient-year). Although a statistical significance for this difference could not be documented, these results seem to suggest that a complete normalisation of $\mathrm{HbA}_{1 \mathrm{c}}$ may represent a risk, amongst others, of $\mathrm{DH}$, and therefore should be recommended only under certain conditions as a target of insulin therapy for Type 1 diabetic patients.

Pending the documentation of long-term benefits of normal vs. slightly supranormal $\mathrm{HbA}_{1 \mathrm{c}}$ levels, striving for a degree of glycaemic control equivalent to the so-called "impaired glucose tolerance" with $\mathrm{HbA}_{1 \mathrm{c}}$ levels between 5.6 and $6.25 \%$ (37) and average glycaemia up to $6.8 \mathrm{mmol} / \mathrm{l}(41,61)$ may be justified according to Unger [62], except during pregnancy. Such a policy might possibly reduce the risk of disabling hypoglycaemia without introducing a significant risk of microangiopathic diabetic late complications [37, 61].

In conclusion, the present results indicate that under the policies of this diabetes centre, CSII was maintained during a mean of 4.5 years by a majority $(83 \%)$ of experienced adult Type 1 diabetic patients. At a mean $\mathrm{HbA}_{1 \mathrm{c}}$ of $6.7 \%$ the metabolic control of most of these patients was very satisfactory and compares favourably with the results achieved in similar follow-up studies on the quality of care in Type 1 diabetic patients under the conditions of intensified insulin therapies.

Acknowledgements. We are indebted to Dr. Gabriele E. Sonnenberg, Milwaukee, USA, who was instrumental in the organisation of our CSII program until 1986. The dedicated cooperation of the former diabetes nurses Mrs. Astrid Weinrebe and Mr. Michael Brormann during the course of these studies and the financial support of the Peter KJöckner Foundation, Duisburg, FRG, are gratefully acknowledged.

\section{References}

1. Slama G, Hautecouverture M, Assan R, Tchobroutsky G (1974) One to five days of continuous intravenous insulin infusion in seven diabetic patients. Diabetes 23: 732-738

2. Pickup JC, Keen H, Parsons JA, Alberti KGMM (1978) Continuous subcutancous insulin infusion: an approach to achieving normoglycaemia. Br Med J 1: 204--207

3. American Diabetes Association (1985) Policy statement: continuous subcutaneous insulin infusion. Diabetes 34: 946-947

4. Schade DS, Santiago JV, Skyler JS, Rizza RA (1983) Intensive insulin therapy. Fxcerpta Medica, Princeton NJ

5. Calabrese G, Bueti A, Santeusanio F, Giombolini A, Zega G, Angeletti G, Cartechini MG, Brunctti P (1982) Continuous subcutaneous insulin infusion treatment in insulin-dependent diabetic patients: a comparison with conventional optimized treatment in a long-term study. Diabetes Care 5: 457-465

6. Home PD, Capaldo B, Burrin JM, Worth R, Alberti KGMM (1982) A cross-over comparison of continuous subcutaneous insulin infusion (CSII) against multiple injections in insulin-dependent diabetic subjects: improved control with CSII. Diabetes Carc 4: 466-471

7. Nathan DM, Lou P, Avrouch J (1982) Intensive conventional and insulin pump therapy in adult type-I diabetes. Ann Intern Med 97: 31-36

8. Brink SJ, Stewart C (1986) Insulin pump treatment in insulindependent diabetes mellitus: children, adolescents, and young adults. JAMA 255: 617-621

9. Berger M, Sonnenberg GE, Chantelau E: (1982) Insulin pump treatment for diabetes: some questions can be answered already. Clin Physiol 2: 351355

10. Daubresse JC, Henrivaux P, Bailly A, Lemy C, Duchateau A (1983) Long-term managcment of insulin-treated diabetic patients with continuous subcutaneous insulin infusion. Diabete Metab (Paris) 9: 45-52

11. Chantelau E, Bockholt M, Lie KT, Brocrmann C, Sonnenberg GF, Berger M (1983) Diet and pump-treated diabetes: a long-term follow-up. Diabete Metab (Paris) 9: 277. 282

12. The Kroc Collaborative Study Group (1984) Blood glucose control and the evolution of diabetic retinopathy and albuminuria. $\mathrm{N}$ Engl J Med 311:365-372

13. Bending JJ, Pickup JC, Keen H (1985) Frequency of diabetic ketoacidosis and hypoglycaemia coma during treatment with continuous subcutaneous insulin infusion. Audit of medial care. Am J Med 79: 685-691

14. Leichter SB, Schreiner MF, Reynolds LR, Bolick T (1985) Longterm follow-up of diabetic patients using insulin infusion pumps. Arch Intern Med 145: 1409...1412

15. Mecklenburg RS, Benson FA, Benson JW, Blumenstein $B \Lambda$, Fredlund PN, Guinn TS, Metz RI, Nielsen RL (1985) Long-term metabolic control with insulin pump therapy. N Engl J Med 313: $465-468$

16. Ronn B, Mathisen ER, Vang L, Lorup B, Deckert T (1987) Evaluation of insulin pump treatment under routine conditions. Diabetes Res Clin Pract 3: 191-196

17. Rønn B, Vang L, Deckert T (1988) Seven years of routine insulin pump treatment. In: 7th Workshop of the AIDSPIT-Study Group, booklet of abstracts. January 31-February 2, 1988, Igls (Austria)

18. Knight $G$, Jennings $A M$, Ward DJ (1988) Outcome of a 5-year programme of glycacmic control intensification using CSII. Diabetes 37 [Suppl 1] $25 \mathrm{~A}$ (Abstract)

19. WHO-Study Group (1985) Diabetes mellitus. Technical Report Series 727. Geneva (Switzerland)

20. Editorial (1978) The policy of the European Association for the Study of Diabetes on human investigation. Diabetologia 15: 431-432

21. Pickup JC, Rothwell D (1984) Technology and the diabetic patient. Med Biol Eng Comput 22:385-400

22. Kraegen $\mathrm{EW}$, Chisholm IJJ (1984) Insulin response to varying 
profiles of subcutaneous insulin infusion: kinetic modelling studies. Diabetologia 26: 208213

23. Scheen A, Castillo $M$, Jandrain B, Krzentowski G, Henrivaux P, Luyckx AS, Lefebvre P (1984) Metabolic alterations after a twohour nocturnal interruption of continuous subcutaneous insulin infusion. Diabetes Care 7: 338-342

24. Scheen AJ, Henrivaux P, Jandrain B, Lefebvre P (1986) Anti-insulin antibodies and metabolic deterioration after interruption of continuous subcutaneous insulin infusion. Diabetes Care 9: 673.674 (Letter)

25. Chantelau E:, Sonnenberg GE, Best F, Heding I.G, Berger M (1984) Target fasting glycaemia for pump-treated type-I diabctics. Klin Wochenschr 62: 328--330

26. Sonnenberg GE, Chantelau E, Berger M (1873) Educational aspects of insulin pump treatment in type-I diabetic patients. In: Assal JP, Berger M, Canivet J, Gay N (eds) Handbook of diabetes education. Excerpta Medica. Amsterdam, pp 7077

27. Chantelau E, Lange G, Sonnenberg GE, Berger M (1987) Acute cutaneous complications and catheter needle colonization during insulin pump treatment. Diabetes Care 10:478-482

28. Assal JP, Mühlhauser I, Pernet A, Gfeller R, Jörgens V, Berger M (1985) Patient education as the basis for diabetes care in clinical practice and research. Diabetologia 28: 602-613

29. Mühlhauser I, Bruckner I, Berger M, Cheta D, Jörgens V, Ionescu-Tirgoviste C, Scholz V, Mincu I (1987) Evaluation of an intensified insulin treatment and teaching programme as routine management of Type-1 (insulin-dependent) diabetes: the Bucharest-Düsseldorf study. Diabetologia 30: 681-690

30. Champion MC, Bchme M, Dupre J, Galbraith J, Radziuk J, Rodger NW, Ruston M (1981) Continuous subcutaneous infusion of insulin (CSII) in insulin-dependent diabetes mellitus: 17 subject years in 11 voluntecrs. Clin Invest Med 4: 33 B (Abstract)

31. Chantelau E, Gösseringer G, Sonnenberg GE, Berger M (1985) Moderate intake of sucrose does not impair metabolic control in pump-treated diabetic outpatients. Diabctologia 28: 204-207

32. Chantelau E, Spraul M, Kunze K, Sonnenberg GE, Berger M (1986) Effects of the glycaemic index of dietary carbohydrates on prandial glycaemia and insulin therapy in type-I diabetes mellitus. Diabetes Res Clin Pract 2: 35-41

33. Melberg SG, Havelund S, Villumsen J, Brange J (1988) Insulin compatibility with polymer materials used in external pump infusion systems. Diabetic Med 5: 243 - 247

34. Marshall SM, Home PD (1986) Which pump? Diabetic Med 3: 190-191

35. The DCCT Research Group (1987) Diabetes control and complications trial (DCCT): results of a feasibility study. Diabetes Carc 10: 1.19

36. National Diabetes Data Group (1984) Report of the expert comittee on glycosylated hemoglobin. Diabetes Care 7:602-606

37. Littlc RR, England JD, Wicdmeyer H-M, McKenzie EM, Pettitt DJ, Knowler WC, Goldstein DE (1988) Relationship of glycosylated hemoglobin to oral glucose tolerance. Diabetes 37:60-64

38. Mühlhauser I, Sawicki P, Berger M (1986) Cigarette-smoking as a risk factor for macroproteinuria and proliferative retinopathy in Type 1 (insulin-dependent) diabetes. Diabetologia 29: 500-502

39. Morris JA, Gardner MJ (1988) Calculating confidence intervals for relative risks (odds ratios) and standardised ratios and rates. $\mathrm{Br}$ Med J 196: 1313-1316

40. Pickup JC (1984) Pumps in practice: practical aspects of continuous subcutaneous insulin infusion (CSII). Diabetic Med 1:27 32

41. Nathan DM, Singer DF:, Hurxthal K, Goodson JD (1984) The clinical information value of the glycosylated hemoglobin assay. N Engl J Med 310: 341-346

42. Mann JI, Lewis B, Shepherd J, Winder AF, Fenster S, Rose I, Morgan B (1988) Blood lipid concentrations and other cardiovascular risk factors: distribution, prevalence, and detection in Britain. Br Med J 296: 1702 1706

43. Teusch SM, Herman WH, Dwyer D, Lane M (1984) Mortality among diabetic patients using continuous subcutaneous insulininfusion pumps. N Engl J Med 310: 361-368
44. Schiffrin A, Belmonte M (1982) Multiple daily self-glucose monitoring: its essential role in long-term glucose control in insulin-dependent diabetic patients treated with pump and multiple subcutaneous injections. Diabetes Care 5: 479.484

45. Nathan DM (1983) The importance of intensive supervision in determining the efficacy of insulin pump therapy. Diabetes Care 6: 295297

46. Peyrot M, Rubin RR (1988) Insulin self-regulation predicts better glycemic control. Diabetes 37 [Suppl 1]: $53 \mathrm{~A}$ (Abstract)

47. Mühlhauser I, Jansen M, Berger M (1988) How do c-peptide negative IDDM patients maintain normal glycosylated hemoglobin values? Diabetes 37 [Suppl 1]: 162 A (Abstract)

48. Peden NR, Braaten JT, McKendry JBR (1984) Diabetic ketoacidosis during long-term treatment with continuous subcutaneous insulin infusion. Diabetes Care 7:1-5

49. Knight G, Ward JD (1986) Diabctic ketoacidosis. Lancet II: 1284-1285 (Letter)

50. Pickup JC (1986) Indications, contraindications, and complications of continuous subcutancous insulin infusion. In: SerranoRios M, Lefebvre PJ (eds) Diabetes 1985. Flsevier, Amsterdam, pp 900903

51. Lauritzen T, Pramming S, Deckert 'T, Binder C (1983) Pharmacokinctics of continuous subcutaneous insulin infusion. Diabetologia 24: $326-329$

52. Chisholm DJ, Kraegen FW, Hewett MJ, Furler S (1984) Low subcutaneous degradation and slow absorption of insulin in insulindependent diabetic patients during continuous subcutaneous insulin infusion at basal rate. Diabetologia 27:238-242

53. Skyler JS (1986) Lessons from studies of insulin pharmacokinetics. Diabetes Care 9: 666-668 (Editorial)

54. Home PD, Marshall SM (1984) Problems and safety of continuous subcutancous insulin infusion. Diabetic Med 1:41-44

55. Klein R, Klein BEK, Moss SF, Davis MD, DeMets DL (1988) Glycosylated hemoglobin predicts the incidence and progression of diabetic retinopathy. JAMA 260:2864 2871

56. Chase HP, Jackson WE, Hoops SL, Cockerham RS, Archer PG, O'Brien D (1989) Glucose control and the renal and retinal complications of insulin dependent diabetes. JAMA 261: 1155-1160

57. Aaby Svendsen P, Lauritzen T, Soegaard U, Nerup J (1982) Glycosylated hacmoglobin and steady-state mean blood-glucose concentration in Type 1 (insulin-dependent) diabetes. Diabetologia 23: $403 \cdot 405$

58. Bending JJ, Viberti GC, Bilous RW, Keen H (1985) Eight-month correction of hyperglycernia in insulin-dependent diabetes mellitus is associated with a significant and sustained reduction of urinary albumin excretion rate in patients with microalbuminuria. Diabetes 34 [Suppl 3]: 69-.73

59. Lauritzen T, Frost-Larsen K, Larsen HW, Deckert T (1985) Two year experience with continuous subcutaneous insulin infusion in relation to retinopathy and ncuropathy. Diabetes 34 [Suppl 3] 74-79

60. Tattersall RB, Gale E (1981) Patient self-monitoring of blood glucose and refinements of conventional insulin treatment. Am J Med 70: 177-181

61. Jarrett RJ, Keen H (1980) Towards a target blood glucose in diabetes. Lancet II: 30-31 (Letter)

62. Unger RH (1982) Meticulous control of diabetes: benefits, risks, and precautions. Diabetes 31:479-483

Received: 7 December 1988

and in revised form: 30 March 1989

I)r. H.Chantelau

Diabetes-Ambulanz

MNR-Klinik

Heinrich Heine Universität

Moorenstrasse 5

I)-4000 Düsscldorf

FRG 